\title{
When Materials and Chemistry Meet in the City of Rio de Janeiro
}

José Vicente Calvano1,*, Fernando de Oliveira Marin¹

How to cite

Calvano JV (iD https:/ /orcid.org/0000-0003-0155-1405

Calvano JV, Marin FO (2019) When Materials and Chemistry Meet in the City of Rio de Janeiro. J Aerosp Technol Manag, 11, Special Edition: 1-2. https://doi.org/10.5028/jatm. etmq.01

We are deeply honored to introduce to the reader such special issue of Journal of Aerospace Technology and Management (JATM) containing some of the best manuscripts submitted and presented in the $10^{\text {th }}$ Technical Meeting on Materials and Chemistry (ETMQ10).

The ETMQ10 is a biannual meeting organized by the Brazilian Navy Research Institute (IPqM, <https://www.marinha. mil.br/ipqm/>), being a part of the scheduled activities for science, technology and innovation agenda for 2019 by the General-Directory of Nuclear and Technology Development of the Brazilian Navy (DGDNTM, <https://www.https:// www.marinha.mil.br/dgdntm/>). The event took place in the Post-Graduation and Engineering Research Institute Alberto Luiz Coimbra, of Post-Graduation and Engineering Research from the Federal University of Rio de Janeiro (COPPE/ UFRJ), from November $27^{\text {th }}$ through $29^{\text {th }} 2019$.

The first Technical Meeting on Materials and Chemistry ( $1^{\text {st }}$ ETMQ) was performed in IPqM in November 1994 and was attended by several researchers, technicians, engineers and administrative staff. It consisted on lectures, oral and poster presentations. Since then, ETMQ has been providing a meeting place for all persons related to research and development of new materials and fine chemistry, through the exchange of relevant technical and scientific information. It is also a stimulating environment for the development of science, technology and innovation activities related to the interest of the Brazilian Navy and to the national and international scientific community.

In total, 85 manuscripts were submitted to ETMQ10. Most of them may be considered as a high technical level, and cover topics related to research, development and innovation of materials and chemical processes associated with (but not limited) to naval and aerospace application, such as energetic, ceramic, polymeric, composites and metallic materials.

A partnership was set with the Journal of Aerospace Technology and Management (JATM) in order to publish a list of the highly ranked manuscripts submitted and evaluated by the scientific and editorial committee. The work presented in the selected manuscripts have applications that go beyond the naval area, and are also related to aerospace technology, as is the case for electromagnetic radiation absorbing materials (RAM), propellants, thermal cells and power generation.

\section{HIGHLIGHTS ABOUT ETMQ10:}

- Reception of 85 scientific papers, written by various institutions from all regions of Brazil and from abroad;

- Program with speakers from both national and international relevance, as well as two poster sessions with presentations from researchers, professors, undergraduate and graduate students, as well as from representatives of various companies;

- In an unprecedented way throughout the history of the event, a digital platform was created to index (with DOI number) all submitted and approved manuscript together in an online proceeding available to the general public. Also, a partnership 
was set with Revista Pesquisa Naval (RPN, ISSN 1414-8595 (print) and 2179-0655 (online)) in order to publish highly ranked manuscripts dealing with subjects related exclusively to naval application;

- $\quad$ ETMQ10 was sponsored by the following companies: Companhia Brasileira de Cartuchos (CBC), Nuclebras Equipamentos Pesados (Nuclep), Avibras Indústria Aeroespacial, Empresa Gerencial de Projetos Navais (Emgepron) and Sociedade de Engenharia de Segurança do RJ (Sobes-Rio).

\section{ACKNOWLEDGMENTS}

All administrative staff of the Brazilian Navy Research Institute, as well as of the Navy Technological Center in Rio de Janeiro (CTMRJ, <https://www.marinha.mil.br/ctmrj/>), to which IPqM is subordinated, should be acknowledged and thanked. Special acknowledgment also to COPPE/UFRJ for the support, and to Military Institute of Engineering (IME, <http://www. ime.eb.mil.br/pt/>) for the collaboration. Without its indispensable support of all these institutions the realization of the event, and the publication of this special issue would not be possible. 